2020, Volume 10, International Conference Globalization, Innovation and Development. Trends and Prospects (G.I.D.T.P.), pages: 154-159|

https://doi.org/10.18662/lumproc/gidtp2018/18

\section{Improving \\ Management by \\ Motivating Human Capital within Public Institutions}

\section{Gheorghe Sebastian IACOB*1, Maria-Luiza HRESTIC ${ }^{2}$}

${ }^{1} \mathrm{PhD}$, Doctoral School of Economics and Humanities, Management, "Valahia" University of Targoviste, Romania, sebastian.iacob@yahoo.com Corresponding author

2 Associate Professor, $\mathrm{PhD}$, "Valahia" University of Targoviste, Romania, marrylou1981@yahoo.com
Abstract: The human resource has come to the attention of specialists, especially those in the economic field, when it was found, both at individual and at country level, that the highest profits are due to investment in knowledge, skills, qualification and less in physical capital (machinery, construction, machines, equipment, etc.). The increasing importance of human capital is largely determined by the development of information and communication technologies and, in particular, by the transition to the "knowledge-based economy". The theory of human capital has thus succeeded in supporting and arguing the individual's decision to continue his studies, the differentiation of salary by skill and age, the demand for educational services and medical assistance, the influence of education on growth and economic development, the transmission of economic inequalities from generation to generation, thus contributing to the establishment of educational policies and their correlation with labor market requirements. Human capital is the main wealth of society and the main factor of economic growth. Although it is known that what people produce can be gathered and multiplied, resulting in important aggregates and indices in the economic context, formal education, personal skills and health play an important role in this sense. All are essential constituents of human capital. Also, human capital theory has managed to provide arguments about the individual's decision to continue his studies, to improve educational services and health care, and much more. For society, human capital produces longlasting economic and social effects, making it easier to move from poverty to wealth.

Keywords: buman capital; public institution; knowledge based economy.

How to cite: Iacob, G.S., \& Hrestic, M.-L. (2020). Improving Management by Motivating Human Capital within Public Institutions. In I. Panagoreț \& G. Gorghiu (vol. ed.), Lumen Proceedings: Vol. 10. International Conference Globalization, Innovation and Development. Trends and Prospects (G.I.D.T.P.) (pp. 154-159). Iasi, Romania: LUMEN Publishing House. https://doi.org/10.18662/lumproc/gidtp2018/18 


\section{Introduction}

Everyone can become a manager sooner or later, because you cannot be a manager from the beginning. The degree of manager is obtained in time, according to certain criteria, the experience gathered over time, the seniority accumulated during the career, good efficiency at the workplace, seriousness, ambition and knowledge.

Another aspect refers to the company's customs and nature, company policy and organizational culture, the criteria that leadership imposes when an employee becomes manager.

\section{Theoretical Background}

The function of a manager is a function just like all the other, and it is not a native thing, or one you can inherit, but you learn by applying this occupation day by day [10].

Managers differentiate themselves by the fact that whenever a problem arises, a good manager knows how to solve it no matter what means he uses, and finishes it well, the least trained, regardless of the situation, collapses at a certain moment and does not solve the situation or the problem encountered [7].

In addition to these things, we can add a set of factors that influence the manager's activity. Among these factors, the most important regard the resilience of the manager to change, the physical ability to work, the company's internal environment, the familiarization of the manager with the gradual and continuous emergence of a new technologies [11].

Another factor is the organization's lifecycle, and its ability to cope with external economic pressure, but also the competition of competitors, whether loyal or unfair [14].

\section{Argument of the paper}

The manager faces issues and delicate situations very often, maybe evendaily. These situations that appear, even the goals a manager has to accomplish, are not so easy to solve because they can appear in several departments or environments [20]. A good example would be a problem appeared at the level of the external environment when the company is struggling with a negative image and possibly a poor relationship with the media [8]. 
In this case, the manager faces an organizational problem, and since the company has reached this deadlock, it is a serious situation because customers do not have a very good opinion, and market credibility decreases. The manager has to fight and find a solution to solve this situation [9].

\section{Arguments to support the thesis}

First of all, it should improve relations with the media because, for the most part, the company's situation depends on their relationship with journalists, reporters and those who have a direct impact on the public [18].

Apart from these situations, the manager must also have good collaboration with suppliers. Internally, there is another situation where problems with employees also arise, or situations that need to be quickly resolved [12].

Indeed, it is a long way to go until becoming a successful manager. He has a rather complex and intricate role within the organization.

He deals with the organization of the objectives, planning and tactics of the strategies, after getting informed and collecting all the details, he plans the steps and the process of debate, the development of the objective [16]. After these phases, he divides the duties for each employee or group of employees, not before doing a brief analysis to highlight the people who are effective for that goal. Then, during the course and obviously at the end, the manager must verify the results obtained by employees, he must supervise them with increased attention if the objective is important for the company [13].

Because he has to take responsibility in front of the leadership in case something happens to someone during the process, or another situation, if one of the employees is not effective in achieving the goal. The manager is the intermediate person, between the departments subordinated to him and the leadership [17].

He must always take care of the employees because when the administrator wants some information or simply asks a job-related question, the manager needs to have an answer and know everything that happens in his subordination [15].

In order to prove his professionalism, the manager can make a daily or weekly activity report to send to the superiors and highlight the beneficial things to the company [9]. 


\section{Arguments to argue the thesis}

Human capital has come to the attention of specialists, especially those in the economic field, when it was found, both at the individual and at country level, that the highest profits are due to investment in knowledge, skills, qualification and less in physical capital (machinery, construction, machines, equipment, etc.) [19].

It can be noticed that in human capital theory, education is given an economic value, being a central variable of the quality of human resources and the determinant factor of economic growth [1]. Subsequently, the works of Y. Ben-Porath, M. Blaug, E. Lazear, R. Layard, J. Psacharopoulos, Sh. Rosen, F. Welch and others have played an important role.

\section{Dismantling the arguments against}

Instead, the 1970 s were marked by the promotion of alternative theories of market signals, with P. Tanbman, T. Wales, M. Spencer, J. Stiglitz, K. Arow as representatives. They argued that only a small part of the differences in earnings can be explained by the effects of education on the productive capacities of individuals. J. Stiglitz, P. Tanbman and T. Wales promote the idea that education cannot explain the differentiation of earnings very well, being just a mechanism for selecting more capable people on the labor market [3].

Human capital is given increasing importance, being considered the fundamental factor of economic growth and development, due to profound changes in the economic structures determined by the evolution of technical progress, modernization, mechanization and robotization of production processes. Human capital involves the existence and development of human capacities at all levels of society, locally and nationally, to define and achieve development [5]. "For this reason, under the impact of human capital development, human development-oriented policies have enjoyed interest and support, being treated as key issues of long-term strategies to combat poverty on a global scale, promoted by different organizations and international bodies" [2]. It emphasizes the importance of human capital in the development of society and communities, especially to ensure the continuity of changes and the creation of premises for qualitative progress. 


\section{Conclusions}

Human capital is the main wealth of society and the main factor of economic growth. Although it is known that what people produce can be gathered and multiplied, resulting in important aggregates and indices in the economic context, formal education, personal skills and health play an important role in this. All are essential constituents of human capital. Also, human capital theory has managed to provide arguments about the individual's decision to continue his studies, to improve educational services and health care, and much more. For society, human capital produces longlasting economic and social effects, making it easier to move from poverty to wealth [2].

Development has as starting point the individual level and gradually reaches the social level, being favored by the fulfillment of the human capital, thus enhancing the social cohesion, but also the competitiveness. The emphasis is on the fact that economic and social development is achieved through people, and therefore human capital must be created and increased on the basis of investment in the human being [4].

The success of this process is highlighted by the human development Index, which also highlights the structure and direction of the progress or even the regress of human capital during the economic growth of a country, as well as the issues that accompany this progress. In this context, happiness becomes the key to achieving development [6].

From the point of view of theory, the stock of human capital is considered unlimited, and the human is the only being able to define his strategy, exceeding his limits by progress, hence the human capital is the decisive factor in the building of sustainable economic and social development. The level of education reflects the ability of individuals to acquire knowledge, to communicate and participate in the social life of the community they belong to and to fulfill their social roles. A balance in the distribution of income and investment in human forms the material and socio-cultural framework of man's life expectancy, so that the longevity or ability of the individual to live a long and healthy life is another fundamental feature of human development. Development through people and for people highlights the fourth dimension of human development: participation or opportunities offered to people to participate in and be the protagonists of social life. 


\section{References}

[1]. Iacob S-E, Andronache (Gogeanu) G. The communication paradigms in education. Economie teoretică și aplicată. 2015; 4(615): 217-228. Available from: http://store.ectap.ro/articole/1146.pdf [Accessed 3rd February 2020].

[2]. Molnar M. Sărăcia şi protecția socială. Bucureşti: Ed. Fundația România de Mâine; 1999.

[3]. Murnare R. Alternative views on the quality of education in US, Edean education and economic productivity. Cambridge: Ballinger Publishing Company; 1989.

[4]. Papa Ioan Paul al II-lea. Enciclice. Bucureşti: Ed. ARCB; 2008.

[5]. Perț S. Capitalul uman - Factor cheie al creșterii economice durabile. Convergențe şi disparități, Probleme economice, Nr. 22-23-24, CIDE; 2001.

[6]. Popescu C. Creşterea care sărăceşte. Bucureşti: Ed. Tribuna Economică; 2003.

[7]. Popescu C. Raționalitate şi speranță. Paradigma întregului viu. București: Ed. Renaissance; 2006

[8]. Popescu C, Taşnadi A. Whealth and povertz are inside us, Ecotrend; 2008, November 21-23.

[9]. Radu I. Managementul firmei. Bucureşti: Editura Tribuna Economică; 2001.

[10]. Reich Robert B. Munca națiunilor. Pregătindu-ne pentru capitalismul secolului XXI. București: Ed. Paideia; 1996.

[11]. Schultz Theodore W. Investment in human capital. The American Economic Review, Ed. Economics of Education. 1961; 51.

[12]. Sen A. Dezvoltarea ca libertate. Ed. Economica, București; 2004.

[13]. Iacob SE. "Controversies concerning the concept of sustainable development", published in Valahian Journal of Economic Studies. 2014; 2 (5): 91-98. Available from: http://www.vjes.eu/index.php/archive.html

[14]. Szent-Gyorgyi A. Pledoarie pentru viaţă. Bucureşti: Ed. Politică; 1981

[15]. Walras L. Element of pure economics, Homewood; 1954

[16]. Zamfir C. O nouă provocare: dezvoltarea sociala. Bucuresti: Ed. Polirom; 2006

[17]. UNDP (United Nations Development Program) Romania 2005. Available from: www.undp.ro

[18]. ***. Satisfaction with Life Index Map - Map was published in White, A., 2007. A Global Projection of Subjective Well-being: A Challenge to Positive Psychology Psychtalk, 56: 17-20.

[19]. www.apulum.com

[20]. Schuller T. (***). Les rôle complémentaires du capital humain et du capital social. Available from: www.OCDE.org 